Article

\title{
Sustainability Assessment of Higher Education Institutions in Saudi Arabia
}

\author{
Habib M. Alshuwaikhat *, Yusuf A. Adenle * and Bilal Saghir * \\ Department of City and Regional Planning, King Fahd University of Petroleum \& Minerals, KFUPM Box 1632, \\ Dhahran 31261, Saudi Arabia \\ * Correspondence: habibms@kfupm.edu.sa (H.M.A.); yusuf.microplanet@gmail.com (Y.A.A.); \\ bilal.kfupm@gmail.com (B.S.); Tel.: +966-505-858-990 (H.M.A.); +966-505-678-003 (Y.A.A.); \\ +966-502-289-873 (B.S.)
}

Academic Editor: Marc A. Rosen

Received: 28 June 2016; Accepted: 29 July 2016; Published: 4 August 2016

\begin{abstract}
Universities are paramount change drivers in bringing about a culture of sustainability in society by setting themselves up as models and nurseries for sustainable development. Thus, assessment of sustainability integration within universities is key to their impact on sustainable development. This study conducted an assessment of different public sector universities of Saudi Arabia based on five components: (i) Teaching and Curriculum; (ii) Research and Scholarship; (iii) Campus Operations; (iv) Management and Community; and (v) Financial Management. The sustainability assessment questionnaire (SAQ) was utilized as a tool to discern the component-wise sustainability assessment for Saudi universities. The outcomes of the survey reveal that, in stark contrast with the universities of the developed world, offerings of sustainability relevant academic courses in Saudi Arabia are still lacking. Most Saudi universities still need to integrate research and scholarship in the area of sustainability; sustainable-campus operations in the current scenario are not sufficient. The results also reveal that sustainability-related projects are not prioritized within universities and sustainable financial management practices are not significant. This article concludes by proposing some recommendations emphasizing the importance of adopting sustainability practices in Saudi universities.
\end{abstract}

Keywords: sustainability assessment; sustainable universities; campus sustainability; higher education; Saudi Arabia

\section{Introduction}

In the last few decades, in Higher Education Institutions (HEIs) there have been mounting support and dedication to address sustainability challenges in their institutions. Many universities in different parts of the world are now formulating and implementing numerous sustainable initiatives. Numerous universities have begun the adjustment and restructuring of their teaching and curriculum, research and scholarship, campus operations, community outreach, and financial management to concentrate more on sustainable development and integrate sustainability into everyday campus operations, management, and development [1,2]. Sustainable development (SD) is defined by the Brundtland Report of 1987 as development that "meets the need of the present generation without compromising the ability of future generations to meet their needs" [3]. The integration of SD into campus operations is a result of the need to mitigate the impacts of universities and other HEIs' operations and activities on the natural environment and also to improve university students' sustainability literacy and sustainable behaviors $[4,5]$.

An agglomeration of tools has been initiated for the evaluation of sustainability struggles and integrating sustainable development in advance education [6,7]. Examples of such tools are the 
Good Company's Sustainable Pathways Toolkit [8]; the Auditing Instrument for Sustainability in Higher Education developed by the Dutch Committee on Sustainable Higher Education (CDHO) and Niko Roordia [9] in 2001; and the Sustainability Tracking, Assessment and Rating System (STARS), developed by the Association for Advancement of Sustainability in Higher Education (AASHE) [10]. Others include the Campus Sustainability Assessment Framework for Canadian Universities (CSAF) developed by Cole in 2000; the Sustainability Competency and Opportunity Rating and Evaluation (SCORE) developed by Sustainable Measures; and a Sustainability Assessment Questionnaire (SAQ) developed by University Leaders for a Sustainable Future (ULSF) [11] between 1999 and 2001 with input from many stakeholders. The SAQ is a qualitative questionnaire that assists in assessing the extent to which HEIs are sustainable in important aspects of higher education. Many HEIs have conducted campus sustainability assessments, which differ in scope by putting into context local and critical dimensions of sustainability.

However, not too many universities in the developing world, most especially in the Middle East and North Africa (MENA) region, have carried out campus sustainability assessments through the use of SAQ. In addition, most Middle East and Saudi universities are not doing the required restructuring and adjustment to integrate sustainability. Many scholars clamor for a comprehensive and "whole-university" approach, which would reconsider how higher education can handle and manage sustainability challenges by not only adjusting research and curriculum, but likewise through encouraging community participation and cooperation with several university stakeholders [12-14].

In 1990, a group of university leaders unified behind the Talloires Declaration, a declaration for sustainability in HEIs [15]. Two decades later, around 421 presidents of HEIs from 52 countries have signed the declaration, with a whopping 165 from the United States of America. Several other organizations have also contributed immensely in championing sustainability efforts. The Association of University Leaders for a Sustainable Future (ULSF) was created with the sole purpose of supporting sustainability as a crucial attention of research, teaching, operations, and community outreach at HEIs all over the world via research, publications, and assessment [16]. Second Nature was later established in 1993 to bring about a sustainable world via the transformation of higher education, supporting leaders of HEIs to make their institutions just, healthy, and livable for all [17]. The Australasian Campuses Towards Sustainability (ACTS) was established in 2006 with the sole aim of promoting global dialogue in relation to sustainability in higher education and gained momentum by joining with the Environmental Association for Universities and Colleges (EAUC) in the United Kingdom as well as with the Association for the Advancement of Sustainability in Higher Education (AASHE) in the United States to distribute member resources around the world.

In spite of the significance of the Sustainability Assessment Questionnaire (SAQ) [11], declarations on higher education, and specific policies for advancing universities' environmental sustainability, there remains a research gap in the context of Saudi Arabia, creating an opportunity to assess university sustainability from a holistic perspective. In recent years, some universities launched unstructured green initiatives that encountered implementation difficulties due to the absence of sustainability comprehension and insufficient experts in sustainability. The King Fahd University of Petroleum and Minerals (KFUPM), in its recent strategic plan of 2012, incorporated campus sustainability as its core component, while King Abdulaziz University (KAU) aims by 2020 to achieve leading reforms through integrating sustainability educational programs, research, and practice. The specific vision of KAU is a "world class university with sustainability and community engagement" [18]. In King Abdullah University of Science and Technology (KAUST), sustainable development is an integral part of the university overall mission, and in 2010 the campus earned a Platinum rating on the Leadership in Energy and Environmental Design (LEED) scale. This is based on the campus's innovative and sustainable architecture.

Although there are hundreds of well-established HEIs around the world partaking in organizations and declarations on sustainability, it is observed that such initiatives are lacking in the Saudi context. Earlier studies that have addressed the assessment of universities at the national level 
are mostly carried out in developed countries and not within the MENA region. Related examples of such assessment/framework were carried out in the United States [19], Canada [20], and the United Kingdom [21]. Other studies were on HEIs' students' perception and assessment of campus sustainable development in the United States [4,22,23], Germany [24], the United Kingdom [25], Australia [26], and many more. A recent study carried out in Saudi Arabia investigated students' assessment of campus sustainability at the University of Dammam via the use of an SAQ [27]. No complete and consolidated program is in place in any HEIs in the Kingdom. Therefore, this study seeks to fill this gap by conducting an assessment in public sector universities within the Kingdom. The findings of this assessment will help Saudi universities realize the goals of achieving environmental sustainability, preservation of resources, and protection of the natural environment of the Kingdom, as contained in the recent Saudi vision for 2030.

The next section of this article gives a review of sustainability in higher education and the growth rate experienced in Saudi universities within the last two decades and the need for the adoption of sustainable practices. Followed by this is the methodology, results, and discussion, rounded off with conclusions and recommendations.

\section{Sustainability in Higher Education}

Sustainability has been broadly acknowledged as a paramount objective to be achieved in several countries and across the continents of the world. Its genesis is a result of the world awareness that initiatives on economic development in the enhancement of production must include the protection of the environment besides social justice and the eradication of human challenges [28]. The concept of sustainability is safeguarded within the United Nations' Millennium Development Goals (MDGs) and millennium improvement goals, the European Union's (EU) Sustainable Development Strategy, and several international declarations, initiatives, policies, national laws [29], and the recent United Nations Sustainable Development Goals (SDGs) initiative. In the last few years, issues of sustainability have turned out to be a major focus; it is necessary to balance protecting the natural environment with improving quality of life for both present and future generations in the third world and the developing economy of the world [30]. However, sustainability cannot be regarded as an end in itself or a point of relation but rather a process that is ongoing [31].

According to Alshuwaikhat and Abubakar, awareness regarding the impacts of different campus operations and activities on environment has made sustainability a global concern [32]. For instance, UNESCO declared the United Nations "Decade of Education for Sustainable Development" with the aims of acknowledging education as a basis for SD and embedding SD into systems of education [33]. Numerous universities have initiated a discussion about this concept and the means to integrate it into a university's policies and activities [30]. Universities play a key role in stressing the needs for sustainability within society. As explained by Cortese, universities have key responsibilities in increasing knowledge, awareness, and technology with the goal of developing an environmentally sustainable future [34]. Universities are equipped with all the required capabilities for the development of an intelligent and theoretical agenda to achieve this objective. In addition, universities perform their duties in education, research, policy development, and community outreach and information exchange to help in creating a just and sustainable future. Universities symbolize the cutting edge of information and must be institutions of advanced thinking [35].

Universities and other governmental institutions have developed more than 31 declarations (such as the Stockholm Declaration in 1972, the Talloires Declaration in 1990, the World Declaration on Higher Education in 1998, the Declaration of Barcelona in 2004, the Graz Declaration in 2005, the Sapporo Declaration in 2008, and the Lubeck Declaration in 2009) on sustainability in higher education (SHE), signed by more than 1400 universities globally [36]. Aptitude in sustainability is constructed by means of learning in the classroom and hands-on problem solving techniques. The results of going green seem to be considerable as institutions reap fiscal and community participation benefits along with enriched student learning. If higher education institutions continue implementing green/ecological 
initiatives and integrating sustainability into their teaching and curriculum, research and scholarship, campus operation activities, and community and financial management, the professionals of student affairs might feel an obligation to support green initiatives.

A review of renowned universities from different parts of the world shows that the best-known universities are implementing numerous initiatives and best practices to become sustainable. These include: (i) incorporating environmental and sustainability themes into curricula and research within diverse academic programs, centers, and initiatives that emphasize sustainable issues in their scholarly work. This allows students to learn about sustainability and prepare for the practice of addressing global challenges; (ii) mandating that every thesis/final project include a sustainability impact assessment, the provision of funds/scholarships for research and educational initiatives, and focusing on the pressing issues relating to sustainability. This gives room for students, faculty members, and scholars to contribute to sustainability-related research projects; (iii) upgrading lighting systems by installing new energy-efficient bulbs, reducing greenhouse gas outflows, managing energy, decreasing waste, and improving transportation and operation efficiency; (iv) meeting at regular intervals with staff, faculty members, and students to evaluate prevailing efforts and recommend new approaches. Some of the new approaches include concern and respect for all communities in which the universities participate socially and ecologically through partnership/collaboration with stakeholders; and (v) execution of the full costing strategy and sustainability assessment and reporting [20,37].

As a result, universities all over the world are beginning to become more proactive in propagating sustainability as well as becoming sustainable by ways of teaching and curriculum, research, campus operations, and community outreach [38,39]. According to Cole and Wright, a sustainable campus is a community that "acts upon its local and global responsibilities to protect and enhance the health and wellbeing of humans and ecosystems" and advances some ways of addressing our present and future ecological and social challenges [20] (p. 30).

The increase in the number of universities in the Kingdom of Saudi Arabia in recent decades indicates its attention towards sustainable national development and enhanced human capital across all the regions within the Kingdom. The Kingdom provides humongous investments into building universities to sustain the growing demand on higher education. As of 1995, there were only seven universities located within Makkah, Riyadh, Al-Madinah, and the Eastern Region. In the year 2000, the National Spatial Strategy (NSS) was passed to achieve long-term spatially balanced development between and within all regions across the Kingdom of Saudi Arabia with universities and other infrastructure along transport corridors [40]. After the enactment of the NSS, universities developed rapidly to meet the needs of sustainable and balanced development in all regions. During the 7th NDP (2000-2004) [41], in addition to the NSS, the council of ministers' resolution 212 of 2000 approved the private colleges' bylaw. Also, Royal Decree 7/B/6024 of 2003 approved the university bylaw. Two private universities were established as of 2000. The number of private universities increased to four by 2005 and nine by 2015. As indicated in Table 1, there are currently 25 public universities and nine private universities, making a total of 34 universities spread across all regions of the Kingdom and extending the accessibility of higher education to the majority of the Kingdom's population. Also established is the Saudi Electronic University, which is an online university, established by royal decree on 8 October 2011. Also in existence is the Yanbu and Jubail University College, run under the observation of the Royal Commission for Jubail and Yanbu (RCJY). Looking at the prospects for higher education in the Kingdom, the recently launched Saudi Arabia Vision 2030 aims at allocating educational institutions in prime areas within the cities and having no less than five Saudi universities in the league of topmost universities in international rankings. 
Table 1. Growth of Saudi universities, 1990-2015 [42].

\begin{tabular}{ccccc}
\hline \multirow{2}{*}{ Year } & \multicolumn{3}{c}{ Number of Universities } & \multirow{2}{*}{ Number of University Growth Rate (\%) } \\
\cline { 2 - 4 } & Pubic & Private & Total & - \\
\hline 1990 & 7 & 0 & 7 & 0 \\
1995 & 7 & 0 & 7 & 43 \\
2000 & 8 & 2 & 10 & 50 \\
2005 & 11 & 4 & 15 & 113 \\
2010 & 24 & 8 & 32 & 6 \\
2015 & 25 & 9 & 34 & \\
\hline
\end{tabular}

The consequences of the growth experienced in Saudi university campuses include but are not limited to an increase in demand for energy and housing for staff and students, increase in waste generation, etc. These require sustainable development practices within the campuses. However, such practices to endorse sustainability should not be confined to campus operations only; rather, they should extend to students' attitude-acknowledging its necessity for societal gains. This ultimately means achieving a greater sense of social responsibility for sustainable urban, regional, and local development, which will increase efficiency in resource utilization. Considering these aspects, the aim of this study is to utilize Saudi public sectors universities to conduct a more inclusive sustainability assessment that extends beyond physical components by encompassing five core areas of (a) teaching and curriculum; (b) research and scholarship; (c) campus operations; (d) management and community; and (e) financial management. The methodology of this study in the subsequent section details how the study was carried out.

\section{Methods}

\section{Data Collection and Analysis}

In assessing the sustainability practices in the Saudi universities, a survey using a self-administered questionnaire was conducted in different public sector universities across the country. Based on the Ministry of Education's official approval of the initiative to assess the status of Saudi universities, the questionnaire was sent to all government universities. The study utilized the Sustainability Assessment Questionnaire (SAQ) [11] as the instrument for carrying out the survey by considering the research nature and local context of Saudi Arabia. The questionnaire assesses the integration of sustainability into universities. Besides the personal information and comments/suggestions, the questionnaire consisted of five parts: (1) Teaching and Curriculum; (2) Research and Scholarship; (3) Campus Operations; (4) Management and Community; and (5) Financial Management. The first part assesses the teaching and curriculum sustainability practices in Saudi universities (using 13 questions), with the prime purpose of identifying whether there are any sustainability specific degree programs and/or relevant mandatory courses for students and the extent of sustainability focus in various disciplinary and interdisciplinary education. The second part, consisting of 12 questions, assesses the sustainability aspects concerning research and scholarship in Saudi universities. It includes the extent of the university's involvement in sustainability-oriented research and associated scholarship opportunities for faculty and students; integration of local and global sustainability issues in the university's research agenda; the existence of specific sustainability units/centers; and research outputs in fields related to sustainability. The third part (comprising 18 questions) appraises the sustainability practices in campus operations of Saudi universities. The assessment includes areas of building construction and renovation, energy conservation policies and initiatives, waste reduction practices, recycling of solid waste, food programs, water conservation practices, landscaping, transportation programs, and green purchasing. The fourth part (with 13 questions) assesses the sustainability practices in management and community works of Saudi universities. The assessment targets strategy planning and administration; faculty and staff 
development and rewards; and student opportunities. The fifth part, consisting of 12 questions, assesses the financial sustainability practices in Saudi universities. It includes financial management and diversified sustainable income opportunities as well as the mechanisms involved to ensure long-term financing for research and supporting activities.

The questions in parts 1-5 were mostly closed questions that required responses on a five-point Likert scale (from Strongly Agree to Strongly Disagree), except for Part 1 (i.e., Teaching and Curriculum), which contained two open-ended questions that required the universities to list the academic programs/concentrations as well as courses related to sustainability; and Part 2 (i.e., Research and Scholarship), in which three questions required responses on a five-point percentage (\%) scale (from $0 \%$ to more than $20 \%$ ).

Clearly, whenever the requirement and variables of interest for analysis were identified by researchers, the SAQ would be considered an effective and efficient tool for data collection [43]. The overall response rate of the universities was $44 \%$. The neutral responses were calculated for clarification but not made part of the overall results interpretation due to their non-applicability in defining the current scenario. The assessment criteria in Table 2 were used to answer the questionnaire.

Table 2. Assessment criteria.

\begin{tabular}{|c|c|c|}
\hline Criteria & Reference for Respondent & Criteria for Assessment \\
\hline Strongly Agree & Total agreement with the statement/practice & \multirow{2}{*}{ Comply with the situation } \\
\hline Agree & Agree with the statement/practice & \\
\hline Neutral & No information & Not applicable \\
\hline Disagree & Disagree with the statement/practice & \multirow{2}{*}{ Does not comply with the situation } \\
\hline Strongly Disagree & Total disagreement with the statement/practice & \\
\hline
\end{tabular}

The survey responses were computed into the SPSS software and later coded for analysis. The results in frequency distribution were later converted into percentages to give a desirable as well as acceptable comparison among the different categories.

\section{Results and Discussion}

\subsection{Teaching and Curriculum Related to Sustainability}

In providing answers to the world's unsustainable ways of life, HEIs focus on educating students by incorporating environmentally friendly education into their teaching and learning system [44]. According to Wright, the curriculum is an important means for universities to promote ecological literacy among students [12]. By realizing environmental and social justice concepts such as the impacts of human activities on the biosphere, better understanding of global interactions will emerge. In order to investigate the extent to which Saudi universities' teaching and curriculum are related to sustainability issues, 13 questions (i.e., two open-ended and 11closed) were asked. The results in Table 3 show that only $50 \%$ of Saudi universities offer specific programs or concentrations related to sustainability, while only $27.8 \%$ have specific courses related to sustainability. Regarding the integration of sustainability topics in taught courses, $55.6 \%$ of universities responded positively, showing the need to integrate sustainability into the taught programs. This shows that the current situation in Saudi universities in terms of offering specific courses, programs, and/or concentration as well as taught programs relating to sustainability is still at an early stage. This is contrary to the situation at renowned institutions from the developed world that have already adopted such practices. For instance, faculty members at Georgetown University incorporate environmental and sustainable themes into their research and curricula, while the University of Wisconsin Madison offers a wide variety of courses with sustainability content. Also, based on the study conducted by Bonney and Duram in 2016 in 
ascertaining the total sustainability curriculum at STARS institutions, Western Washington University has a $63 \%$ total sustainability curriculum [45].

Table 3. Teaching and curriculum covering sustainability.

\begin{tabular}{lccc}
\hline \multicolumn{1}{c}{ Teaching \& Curriculum } & \multicolumn{2}{c}{$\%$ of Saudi Universities } \\
\cline { 2 - 4 } & Yes & Neutral & No \\
\hline Universities offer specific program/concentration on sustainability & 50.0 & - & 50.0 \\
\hline Universities offers specific courses related to sustainability & 27.8 & 44.4 & 27.8 \\
\hline Integration of sustainability topics in taught courses & 55.6 & 27.8 & 16.6 \\
\hline $\begin{array}{l}\text { Local sustainability issues and challenges are addressed in } \\
\text { university's teaching programs }\end{array}$ & 44.5 & 33.3 & 22.2 \\
\hline $\begin{array}{l}\text { Students from different backgrounds are required to take at least one } \\
\text { course on issues related to sustainability }\end{array}$ & 57.1 & 11.1 & \multirow{2}{*}{31.8} \\
\hline
\end{tabular}

The survey results also show that less than half (44.5\%) of universities address within their teaching programs local challenges related to sustainability, which young people must understand if we are to move towards sustainable development. Mandating that students take a certain number of sustainability-related courses could be an effective measure of highlighting the importance of sustainability among graduates. In this connection, there exist, encouragingly, a higher percentage of Saudi universities $(57.1 \%)$ having mandated their students to take a minimum of one course on sustainability as compared to $31.8 \%$ that do not have such a requirement.

The results in Figure 1 show that Natural sciences with $55.6 \%$ followed by Engineering and Applied sciences with 55.5\% and Social sciences with 50.0\% come first, second, and third respectively, in terms of sustainability focus. Physical sciences with $44.5 \%$ and Arts and Humanities with $44.4 \%$ are less focused as compared to the aforementioned disciplines in recognizing sustainability aspects, whereas Medical and Health sciences with $37.8 \%$ are the least focused on sustainability.

\section{Sustainability Focus in different Programs}

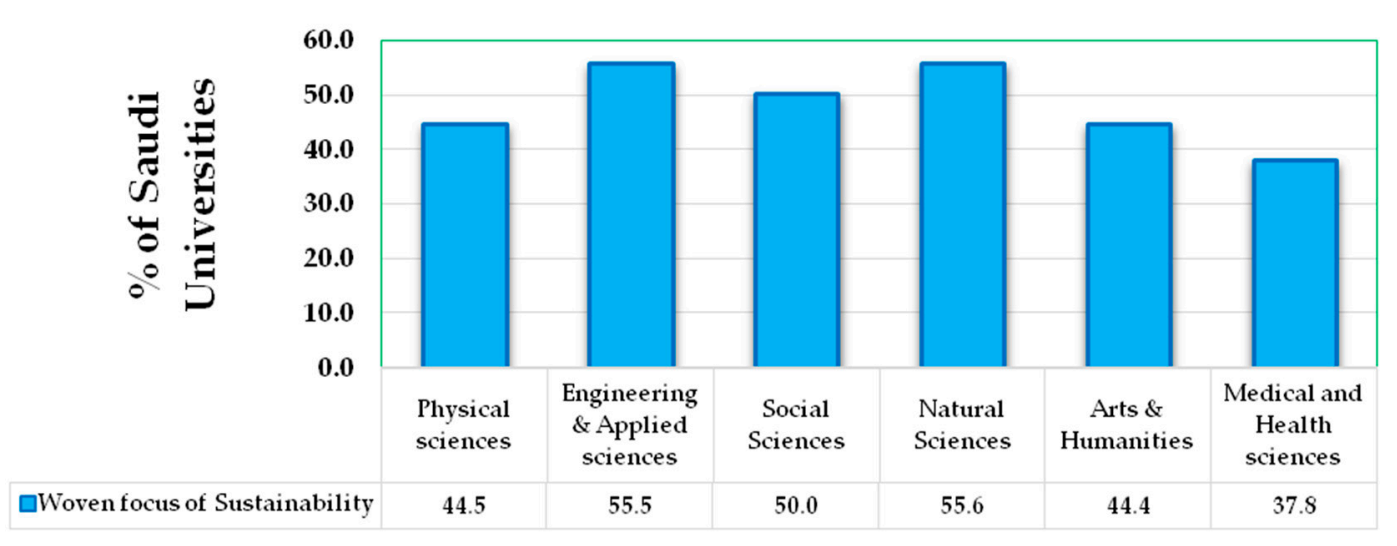

Figure 1. The percentage of Saudi universities that have woven a sustainability focus into different disciplines.

\subsection{Research and Scholarship Related to Sustainability}

In 1999, the Declaration on Science and the Use of Scientific Knowledge accepted at the World Meeting on Science, which was jointly organized by UNESCO and the International Council for Science (ICSU), stated that "the sciences should be at the service of humanity as a whole, and should contribute to providing everyone with a deeper understanding of nature and society, a better quality of life and 
a sustainable and healthy environment for present and future generations (UNESCO, 2012)" [46]. This section reports the extent to which research and scholarship are related to sustainability issues. From the results collected from the SAQ survey, Table 4 shows that $72.2 \%$ of Saudi universities are currently giving priority to sustainability research and encourage consistent scholarships for sustainability awards. However, only $66.7 \%$ of Saudi universities allocate their research funding for faculty members to conduct research in sustainability-related topics/themes. On the academic side, it is important to encourage students to get involved in sustainability-related projects and conduct research in this area. In addition, university graduates and undergraduate students can link their thesis and senior design projects with sustainability issues and challenges. In this regard, the survey results show that $55.6 \%$ and $72.3 \%$ of Saudi universities do encourage their students to conduct sustainability-related research projects and thesis/design projects, respectively, as compared to around $11 \%$ of universities that do not offer such encouragement to their students. This situation is consistent with current practices within renowned international universities. Students, faculty, and scholars at the University of Oregon contribute to sustainability-related research projects ranging from alternative energy green design, community development, environmental issues and policy, sustainable materials and chemistry, to environmental and social justice. The survey results also indicate that $83.4 \%$ of Saudi universities recognize local sustainability issues and challenges and have included such issues in their research agenda. Around $72 \%$ of universities of the Kingdom claim to have collaboration with other institutions and industries in pursuit of solutions to existing sustainability-related challenges. However, only $44.5 \%$ of Saudi universities have established research centers/units conducting research in sustainability areas. This percentage is significantly low and needs to be improved by ensuring the presence of at least one sustainability research unit in every university of the Kingdom. For example, in Cornell University, a total of six centers are supporting the Cornell sustainability agenda in research. Also from the survey, $55.6 \%$ of Saudi universities incorporate sustainability aspects in their research outputs such as journals and conferences publications. From the survey, it is obvious that Saudi universities' adoption of sustainability practices in their research and scholarship programs is insignificant. The funding allocation also reflects the lack of attention Saudi universities give to sustainability-related research. The Sustainability Office at the University of Wisconsin-Madison provides funding for educational and research initiatives from its program "Sustainability Innovation in Research and Education grants." At the Universitat Politècnica de Catalunya (Barcelona), every thesis/final project requires the inclusion of an impact assessment of sustainability.

Table 4. Research and scholarship covering sustainability.

\begin{tabular}{lccc}
\hline \multicolumn{1}{c}{ Research \& Scholarship } & \multicolumn{2}{c}{ \% of Saudi Universities } \\
\cline { 2 - 4 } & Yes & Neutral & No \\
\hline Universities involved in research and scholarship in the area of sustainability & 72.2 & 11.1 & 16.7 \\
\hline $\begin{array}{l}\text { Universities with faculty research funding in the area of sustainability for } \\
\text { various disciplines }\end{array}$ & 66.7 & 16.6 & 16.7 \\
\hline Universities with students involved in sustainability related research projects & 55.6 & 33.3 & 11.1 \\
\hline $\begin{array}{l}\text { Universities encourage sustainability related thesis/senior design projects } \\
\text { by students }\end{array}$ & 72.3 & 16.5 & 11.2 \\
\hline Having local sustainability issues and challenges in their research agenda & 83.4 & 11.1 & 5.5 \\
\hline $\begin{array}{l}\text { Collaborating with other institutions and industries in pursuit of solutions to } \\
\text { sustainability challenges }\end{array}$ & 72.3 & 16.7 & 11 \\
\hline $\begin{array}{l}\text { Having research centers/units/groups for sustainability } \\
\text { Reflecting sustainability aspects in the research outputs e.g., journals and } \\
\text { conference publications }\end{array}$ & 44.5 & 22.2 & 33.3 \\
\hline
\end{tabular}

As a tool for evolving sustainability culture in academia, universities can allocate from their total research budget a special fund to support research projects integrating sustainability aspects. Figure 2 
shows that nearly $40 \%$ of Saudi universities allocate a small fund (1\%-5\% of the total research funding) to support sustainability research. The amount of sustainability research varies across the universities; however, in general, there is low financial support, as evident from the above figure. In addition, $11.1 \%$ of Saudi universities have no specific funding for sustainability-related projects.

\section{Funding devoted to Sustainability related Projects}

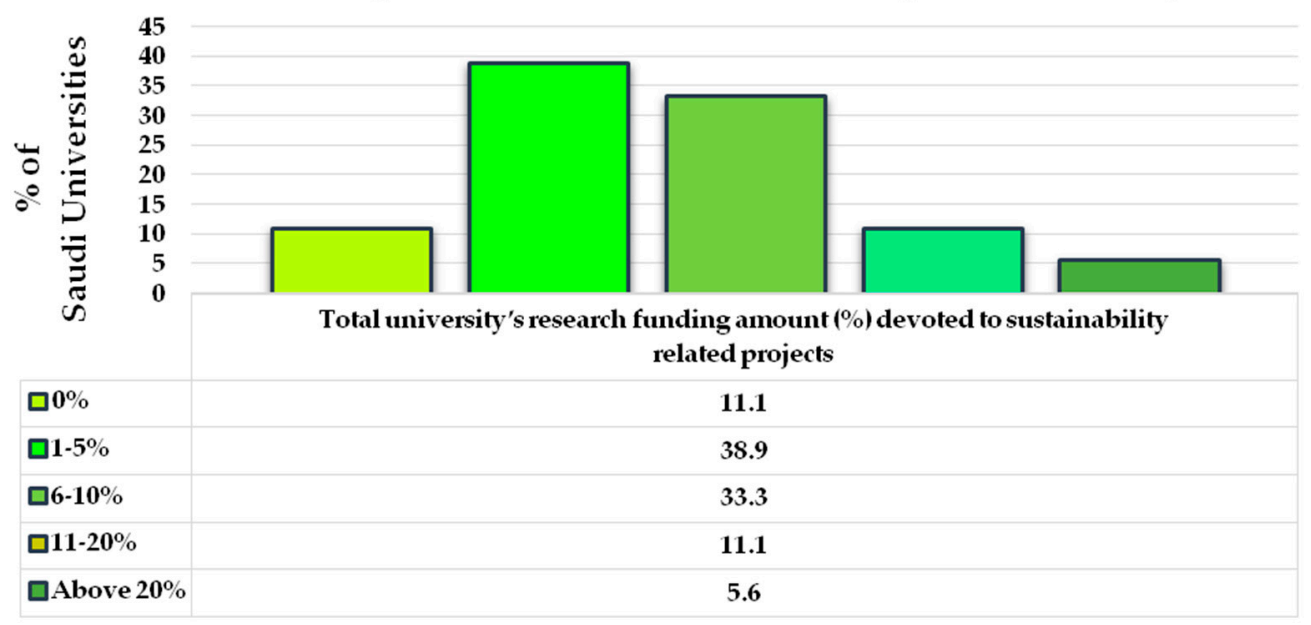

Figure 2. Percentage of Saudi universities allocating funds to sustainability-related projects.

\subsection{Campus Operations Moving toward Sustainability}

The extent to which Saudi universities are adopting sustainability practices in their campus operations is presented in Table 5 .

Table 5. Campus operations moving toward sustainability.

\begin{tabular}{llcc}
\hline \multirow{2}{*}{ Campus Operations } & \multicolumn{2}{c}{ \% of Saudi Universities } \\
\cline { 2 - 4 } & Yes & Neutral & No \\
\hline Energy efficient lighting systems & 55.6 & 22.2 & 22.2 \\
\hline Established efficient cooling (AC) practices & 66.7 & 11.1 & 22.2 \\
\hline Use day-lighting techniques for saving energy & 44.5 & 16.6 & 38.9 \\
\hline Adhere to energy use standards for construction of new buildings & 50.0 & 33.3 & 16.7 \\
\hline Environmental analysis practices for construction and renovation of buildings & 61.1 & 16.7 & 22.2 \\
\hline Initiatives for LEED Certificate of campus buildings & 27.8 & 44.4 & 27.8 \\
\hline Automation and controls systems technology for buildings & 72.2 & 11.1 & 16.7 \\
\hline Practices regarding computer energy savings & 62.2 & 21.1 & 16.7 \\
\hline Solar/Photovoltaic energy systems for renewable energy initiatives & 22.3 & 38.8 & 38.9 \\
\hline Solar hot water systems & 22.2 & 27.8 & 50.0 \\
\hline Program on reducing water consumption on irrigation & 50.0 & 27.7 & 22.3 \\
\hline Water efficient toilets systems & 55.6 & 11.1 & 33.3 \\
\hline Promotes paper usage reduction (double-sided copying) & 44.5 & 11.1 & 44.4 \\
\hline Waste recycling programs/initiatives i.e., paper, plastics, metals, food, etc. & 27.8 & 44.4 & 27.8 \\
\hline $\begin{array}{l}\text { Ensures purchasing from environmentally and socially responsible companies } \\
\text { (green purchasing) }\end{array}$ & 33.4 & 27.7 & 38.9 \\
\hline Public bus transit programs & 38.9 & 11.1 & 50.0 \\
\hline Carpooling program within campus & 27.8 & 33.3 & 38.9 \\
\hline Bicycle-/pedestrian-friendly systems in campus & 16.7 & 33.3 & 50.0 \\
\hline
\end{tabular}


Campus operations is one of the most crucial parts of sustainability in higher education as it directly involves the monetary resources to be utilized. The survey results in Table 5 do not give a positive picture of Saudi universities' on-campus sustainability initiatives. They suggest that Saudi universities are relatively less committed to common energy-saving practices such as energy-efficient lightning and air-conditioning systems, day-light saving practices, and setting energy usage standards for the construction of new buildings when compared with globally recognized universities. This indicates the need for on-campus sustainability initiatives such as improvements in automation and control systems technology for buildings, energy-efficient usage of computers and heating systems, and renewable energy initiatives. Such initiatives still need more recognition and promotion at the campus level to reduce the dependency on and promote savings of energy. Notwithstanding the abundance of energy resources Kingdom-wise, Saudi universities should adopt sustainable energy consumption on their campuses. Only $27.8 \%$ of university campuses of Saudi Arabia are striving for "Leadership in Energy and Environmental Design (LEED)" Certification for their campus buildings.

Saudi universities should adopt exemplary practices in this regard. For instance, Clarkson University, USA focuses on upgrading its lighting systems, including the installation of over 60,000 new energy-efficient T8 fluorescent and outdoor LED bulbs across the whole campus. In addition, the University of Oregon has accomplished major achievements in sustainability, including the Lillis Business Complex, which is a LEED-certified business school and has a recycling program that recovers $47 \%$ of all university waste.

Water is a scarce resource and its consumption costs are significantly high in the Kingdom. Thus, it is equally important for Saudi universities to ensure sustainable on-campus water consumption. At present, almost half of Saudi universities are running programs to reduce water consumption for irrigation purposes, while $55.6 \%$ of Saudi universities have efficient toilet systems in their campuses. The universities consider recycling as a sustainability program and promote the reduction of paper usage in campus by $44.5 \%$; nearly $30 \%$ of Saudi universities have been taking initiatives on waste recycling for paper, plastics, metals, food, etc. In addition, 33.4\% of Saudi universities ensure purchasing from environmentally and socially responsible companies (green purchasing), 38.9\% have sustainable public transit programs on the campuses, and $27.8 \%$ have a carpooling system on campus, whereas only $16.7 \%$ promote bicycle/pedestrian systems.

\subsection{Management and Community Concern about Sustainability}

This part asked 13 questions about the involvement of departments in community engagement activities related to sustainability and the extent to which the institutions utilize their resources for such projects. According to Alshuwaikhat et al., universities can be considered as small cities that affect their environment either directly or indirectly as a result of their operations, population size, and the services they provide within their community [32]. The survey results in Table 6 show that around $61 \%$ of Saudi universities have a well-defined sustainability policy at the university level, while $33.3 \%$ have no such policy. Around $44 \%$ of Saudi universities have established a center with a sustainability officer responsible for overseeing sustainability-related activities; however, around half of universities do not have such a setup. The percentage of Saudi universities having a special link about sustainability on their website accounts for only $27.8 \%$.

The survey results also show that only $22.2 \%$ of universities in the Kingdom consider sustainability aspects as criteria in hiring, promoting, and extension of tenure of faculty and staff members. Half of Saudi universities incorporate sustainability aspects in their strategic plan, whereas just $38.9 \%$ of universities have reflected local sustainability challenges in their sustainability policy. A low percentage of Saudi universities adopt sustainability practices via a policy document or integration into the universities' programs. The survey results in Table 6 also show university efforts in promoting sustainability efforts in the campus community. Around $55.6 \%$ of Saudi universities celebrate environmental days, which is important in highlighting the importance of a sustainable environment. 
Around $33 \%$ of universities have student clubs/societies focusing on sustainability practices within the campus, while only $27.8 \%$ of Saudi universities have significant faculty and staff development opportunities in sustainability. The survey further reveals that only $38.9 \%$ of Saudi universities have adopted sustainability practices in residences or dormitories (e.g., recycling), 38.9\% involve student groups across campus in sustainability initiatives, $11.1 \%$ organize energy competitions in the campus community, and around $50 \%$ are promoting recycling.

Table 6. Management and community concern about sustainability.

\begin{tabular}{lccc}
\hline \multirow{2}{*}{ Management \& Community } & \multicolumn{2}{c}{ \% of Saudi Universities } \\
\cline { 2 - 4 } & Yes & Neutral & No \\
\hline Existence of a well-defined sustainability policy & 61.1 & 5.6 & 33.3 \\
\hline Have a sustainability office/officer & 44.4 & 5.6 & 50.0 \\
\hline Have special link on sustainability on their webpage & 27.8 & 22.2 & 50.0 \\
\hline $\begin{array}{l}\text { Sustainability as a criterion for hiring, promoting, and tenure extension of } \\
\text { faculty and staff }\end{array}$ & 22.2 & 44.5 & 33.3 \\
\hline Integrated sustainability aspects in their strategic plan & 50.0 & 38.8 & 11.2 \\
\hline Reflected local sustainability challenges in their sustainability policy & 38.9 & 27.8 & 33.3 \\
\hline Celebrate environmental days to promote sustainability & 55.6 & 11.0 & 33.4 \\
\hline Societies or student clubs with a sustainability focus & 33.4 & 22.1 & 44.5 \\
\hline Significant faculty and staff development opportunities in sustainability & 27.8 & 33.3 & 38.9 \\
\hline Sustainability practices in residences or dormitories & 38.9 & 27.8 & 33.3 \\
\hline Involve student groups across campus in sustainability initiatives & 38.9 & 16.6 & 44.5 \\
\hline Organize energy competitions among campus community & 11.1 & 38.9 & 50.0 \\
\hline Promote recycling awareness among the community & 50.0 & 16.6 & 33.4 \\
\hline
\end{tabular}

\subsection{Financial Management Related to Sustainability}

Given that financial related sustainability is one of the key challenges that universities/colleges are confronted with, this section reports the Saudi universities' assessment of financial management. Universities are unpredictable and dynamic organizations. Financial management is a vital component of sustainability in Saudi universities. Total spending on education as a proportion of GDP is high for most Middle East and North Africa (MENA) nations, but the assets spent have not brought about the monetary or social advantages expected, as confirmed by the high unemployment rate of university graduates and low advancement yields [47]. Table 7 shows that half of Saudi universities have made financial sustainability an important component of their strategic plan. On the other hand, $55.5 \%$ of universities consider their endowment fund as a long-term financial resource, whereas only $44.4 \%$ Saudi universities reported that the endowment fund is providing a sustainable competitive financial advantage to advance educational and research performance. Similarly, $66.7 \%$ of universities have a policy framework for endowment spending, whereas only $16.7 \%$ have sufficient financial resources to withstand a drop in government subsidies. The universities developing a full costing model to cover all costs account for just $44.5 \%$.

Table 7 above also shows that $44.4 \%$ of universities have diversified their income sources with more financial autonomous powers. Only $38.9 \%$ of Saudi universities are contracting with the private sector for commercialized research, whereas $61.1 \%$ are identifying additional sources of funding by establishing partnerships with the private sector. From the survey, it is evident that only $44.4 \%$ of Saudi universities are pro-active in identifying areas of mutual financial benefit between local and regional partners. Around $40 \%$ of universities have a specific efficiency program to cut down expenses including operating costs, whereas the percentage of universities having designed governance structures and 
human resources management to explore diversification of external resources accounts for $50 \%$ of the total Saudi universities.

Table 7. Financial management for sustainability.

\begin{tabular}{lccc}
\hline \multicolumn{1}{c}{ Financial Management } & \multicolumn{2}{c}{ \% of Saudi Universities } \\
\cline { 2 - 4 } & Yes & Neutral & No \\
\hline Financial sustainability is part of the university's strategic plan & 50.0 & 33.3 & 16.7 \\
\hline Consider endowment fund as a long-term financial resource & 55.5 & 16.7 & 27.8 \\
\hline $\begin{array}{l}\text { Endowment fund to advance the university's educational and } \\
\text { research performance }\end{array}$ & 44.4 & 27.8 & 27.8 \\
\hline Policy framework for endowment spending & 66.7 & 27.7 & 5.6 \\
\hline Can withstand a drop in governance subsidies & 16.7 & 50.0 & 33.3 \\
\hline Developing a full costing model to cover the record of all costs & 44.5 & 49.9 & 5.6 \\
\hline Diversifying sources of income with more financial autonomous powers & 44.4 & 38.9 & 16.7 \\
\hline Contracting with the private sector for commercialized research & 38.9 & 33.3 & 27.8 \\
\hline $\begin{array}{l}\text { Identifying new additional sources of funding by establishing partnerships with } \\
\text { the private sector }\end{array}$ & 61.1 & 22.2 & 16.7 \\
\hline $\begin{array}{l}\text { Pro-active in identifying areas of mutual financial benefit between local and } \\
\text { regional partners }\end{array}$ & 44.4 & 38.9 & 16.7 \\
\hline Specific sufficient program to cut down its expenses, including its operating costs & 38.9 & 44.4 & 16.7 \\
\hline $\begin{array}{l}\text { Designing governance structures and human resources management to explore } \\
\text { diversification of external resources }\end{array}$ & 50.0 & 33.3 & 16.7 \\
\hline
\end{tabular}

The status of Saudi universities from the above survey considering sustainable financial management is disappointing. Financial sustainability is one of the key difficulties for most of the universities. In particular, MENA nations confronted with the test of extension inside financial requirements need to look for far-reaching funding strategies. Funding methodologies coinciding with the objectives of the tertiary education framework are essential. However, European universities have identified certain models to overcome the issues of university financial sustainability. For example, in 2010, the University of Coimbra, Portugal began the execution of a full costing strategy. The benefits of the costing model include, but are not limited to, an efficient and improved allocation of resources based on accurate data that are internally comprehensible, enhanced strategic decision-making, and higher recovery of indirect costs. It also gives a more objective decision-making basis for budget allocation, European Funding Schemes, and their conditions of cost recovery.

\section{Conclusions and Recommendations}

This study was carried out to assess the sustainability practices on teaching and curriculum; research and scholarship; campus operations; management and community; as well as financial management via circulation of SAQ to public sector universities in the Kingdom of Saudi Arabia. The key finding from the survey is that in terms of offering specific courses relating to sustainability, Saudi Arabia is still at an early stage. Less than half of Saudi universities have incorporated the issues and challenges of sustainability into their teaching. Regarding research and scholarship, the survey found that Saudi universities' adoption of sustainability practices in their research and scholarship programs is still insignificant. Most universities still need to redirect their research towards sustainable practices. On the issue of campus operations, Saudi universities have not succeeded very well in bringing efficiency and sustainability into their campus operations. This is in conflict with the massive spending to equip the universities with excellent infrastructure and building new ones. Also, the survey reveals that sustainability-related projects do not link various departments and other stakeholders within campus communities and the larger society. Finally, Saudi universities' commitment to sustainable financial management is not yet significant. 
To this end, the desired transformation of Saudi universities into centers of excellence in sustainability will contribute in achieving the broader goals of environmental sustainability envisioned in Saudi Vision 2030 such as preserving natural resources, increasing the efficiency of waste management, reducing all variety of pollution, and developing an all-embracing recycling projects, with a target of generating 9.5 gigawatts of renewable energy. Also contained in the Saudi Vision 2030 are the new and sustainable public revenue stream, the upcoming King Salman renewable Energy Initiative, and the launching of a "Qawam" program that will increase efficiency in spending, renew financial regulations, and limit waste. The Kingdom's 9th National Development Plan also seeks to achieve SD, conservation of natural resources, as well as protection of the environment. The adoption of sustainable campuses in Saudi universities will make them benchmarks for other universities in the MENA, Gulf Cooperation Council (GCC) nations, and the world over to emulate. This will also make them play a paramount role in advancing sustainable practices in university campuses within and outside the Kingdom. To attain this sustainable status in Saudi Arabia, the following policy recommendations should be intelligently implemented.

(1) On teaching and curriculum. Saudi universities should review the present curriculum and give direction in adopting sustainability standards that are significant and have durable impacts. There should be an implicit integration of sustainability development into educational projects and programs in all fields of studies in all Saudi universities. The universities should include sustainability standards in the educational programs of all undergraduate and graduate courses to give students an opportunity to learn how to plan and implement more sustainable urban and regional centers. The universities should purchase advanced sustainability instruments to keep faculty members updated and bridge the gaps between the current sustainability practices of Saudi Arabia and other renowned universities around the globe. Lastly, all Saudi universities should launch sustainability workshop programs.

(2) On research and scholarship. The Kingdom of Saudi Arabia through the Ministry of Education should include sustainability scholarship/grants/funds in the scholarship program of the Custodian of the Two Holy Mosques to achieve more excellence in university education. Sustainability research in Saudi universities should be undergirded with existing university research grants and funds. Efforts should be made to strengthen the synergy between sustainability research by local and global organizations and set up key performance indicators for national and international exploration. The sustainability information should be properly documented to permit for an assessment of those Saudi universities commitment to sustainability. The Ministry of Education should also establish a sustainability research network as a center for cross-disciplinary joint effort and information sharing to create more grounded sustainability research. Every university should be required to initiate an annual or a monthly sustainability research conference to showcase their research excellence in sustainability.

(3) On campus operations. All Saudi universities should adopt sustainability action plans that will entail the utilization of dynamic transport modes and infrastructure, guiding itemized usage within campuses, decreasing the ecological effect of utilized innovations, and proper administration of e-waste. Also, a sustainability procurement and asset re-use plan to manage the progressing procedure of joining sustainability contemplations into acquisition and acquiring choices over the universities should be adopted. In addition, all Saudi universities should meet targets of reducing greenhouse gases by adopting the most efficient renewable energy projects.

(4) On community and management. Every Saudi university should establish a sustainability unit/center for sustainable development with competent personnel. This unit should maintain and support sustainability activities via a website, networks, articles, and utilization of screens within the university campuses. The unit should also on a continuous basis convene focus groups for in-depth investigation of sustainability topics and hold successive sustainability-centered occasions and presentations. Programs for staffs and students that propagate improvements in their practices at work, home, and dormitories should be developed. Also to be established 
is a project on sustainability that involves open occasions, school visits, meetings, and several other community engagements to give more publicity, enlightenment, and participation for campus sustainability activities at the community level. A sustainability report containing all sustainability activities and assessment results on teaching and curriculum, research and scholarships, campus operations, community and management, and financial management should be prepared and made available to the community via appropriate media.

(5) Finally, on financial management. All Saudi universities should develop a full costing model/strategy and sustainable financial policy framework on campus as well as endowment spending. In diversifying the sources of the revenue base in Saudi universities, strong partnerships with the private sector urgently need to be established to create an improvement in internally generated revenue (IGR).

In conclusion, with the adoption of the National Spatial Strategy (NSS) officially approved by Council of Ministers Decree No. 127 of 28/8/2000 and Royal Decree 7/B/6024 of 2003, the university bylaw gives room for the establishment of new universities in all 13 administrative regions of Saudi Arabia. In addition, with the escalating demand for housing and energy and the huge investment in higher education on the part of the government, it is essential to create sustainable campuses that will bring about safety, functionally efficient utilization of energy, transportation, operations, capital, etc. for both present and future generations. Universities in Saudi Arabia should adopt and modify initiatives of campus sustainability from renowned institutions from around the world. Nevertheless, local considerations should also be incorporated into the adoption and modification of such initiatives.

To the best knowledge of the authors, no comprehensive, complete, and consolidated program is in place in any HEI in the Kingdom. It is believed that the time is now to introduce a National Scheme on Sustainability in Saudi universities to help them rearrange their priorities to consider sustainability as a strategic priority in their teaching and curriculum, research and scholarship, and community and financial management.

Acknowledgments: This paper is an output of the research project \#MoHE1405 entitled "A National Scheme on Sustainability in Saudi Universities", funded by the Ministry of Education. The authors acknowledge the support of the Ministry of Education and King Fahd University of Petroleum \& Minerals, Saudi Arabia.

Author Contributions: Habib M. Alshuwaikhat, who is the originator of this initiative and the research project manager, developed the topic and structure and contributed significantly to the methods, results, and discussion sections of this paper. Yusuf A. Adenle developed and contributed significantly to Sections 1-5. Bilal Saghir's contributions to this study encompass the questionnaire design and data collection using online Google forms, followed by statistical analysis using SPSS and Microsoft Excel.

Conflicts of Interest: The authors declare no conflict of interest.

\section{References}

1. Velazquez, L.; Munguia, N.; Platt, A.; Taddei, J. Sustainable University: What can be the matter? J. Clean. Prod. 2006, 14, 810-819. [CrossRef]

2. Lozano, R. Diffusion of sustainable development in universities' curricula: An empirical example from Cardiff University. J. Clean. Prod. 2010, 18, 637-644. [CrossRef]

3. Brundtland Commission. Our Common Future: World Commission on Environment and Development; Oxford University Press: Oxford, UK, 1987.

4. Viebahn, P. An environmental management model for universities: From environmental guidelines to staff involvement. J. Clean. Prod. 2002, 10, 3-12. [CrossRef]

5. Savanick, S.; Strong, R.; Manning, C. Explicitly linking pedagogy and facilities to campus sustainability: Lessons from Carleton College and the University of Minnesota. Environ. Educ. Res. 2008, 14, 667-679. [CrossRef]

6. Shriberg, M. Assessing sustainability: Criteria, tools and implications. In Higher Education and the Challenge of Sustainability; Springer: Dordrecht, The Netherlands, 2004; pp. 71-86.

7. Lozano, R. Incorporation and institutionalization of SD into universities: Breaking through barriers to change. J. Clean. Prod. 2006, 14, 787-796. [CrossRef] 
8. Good Company. Sustainable Pathways Toolkit for Universities and Colleges: Social and Environmental Indicators for Campuses. Part II: Toolkit Technical Manual; Good Company: Eugene, OR, USA, 2002.

9. Roorda, N. AISHE-Assessment Instrument for Sustainability in Higher Education; Stichting Duurzaam Hoger Onderwijs (DHO): Amsterdam, The Netherlands, 2001.

10. AASHE. "STARS Overview" Association for the Advancement of Sustainability in Higher Education, Philadelphia, PA, USA. Available online: https://stars.aashe.org/pages/about/stars-overview.html (accessed on 17 June 2016).

11. Association of University Leaders for a Sustainable Future (AULSF). Sustainability Assessment Questionnaire (SAQ) for Colleges and Universities; University Leaders for a Sustainable Future: Wayland, MA, USA, 2009.

12. Wright, T.S. Definitions and frameworks for environmental sustainability in higher education. High. Educ. Policy 2002, 15, 105-120. [CrossRef]

13. Beringer, A.; Adomßent, M. Sustainable university research and development: Inspecting sustainability in higher education research. Environ. Educ. Res. 2008, 14, 607-623. [CrossRef]

14. McMillan, J.; Dyball, R. Developing a Whole-of-University Approach to Educating for Sustainability: Linking Curriculum, Research and Sustainable Campus Operations. J. Educ. Sustain. Dev. 2009, 3, 55-64. [CrossRef]

15. University Leaders for a Sustainable Future. The Talloires Declaration, 1990. Available online: http: / / www.ulsf.org/programs_talloires_td.html (accessed on 17 June 2016).

16. Association of University Leaders for a Sustainable Future. Welcome Page. Available online: http://www. ulsf.org (accessed on 17 June 2016).

17. Second Nature, 1993. Available online: http://www.secondnature.org (accessed on 17 June 2016).

18. King Abdulaziz University. Vision and Objectives. Available online: http://www.kau.edu.sa/pages-VisionAnd-Objectives.aspx (accessed on 3 June 2016).

19. Nixon, A.; Glasser, H. Campus Sustainability Assessment Review Project; Western Michigan University: Kalamazoo, MI, USA, 2002.

20. Cole, L.; Wright, T. Assessing Sustainability on Canadian University Campuses: Development of a Campus Sustainability Assessment Framework. Master's Thesis, Royal Roads University, Victoria, BC, Canada. Unpublished work, 2003.

21. Jones, P.; Trier, C.J.; Richards, J.P. Embedding education for sustainable development in higher education: A case study examining common challenges and opportunities for undergraduate programmes. Int. J. Educ. Res. 2008, 47, 341-350. [CrossRef]

22. Earl, C.; Lawrence, A.; Harris, N.; Stiller, S. The campus community and the concept of sustainability: An assessment of college of Charleston student perceptions. Chrestomathy 2003, 2, 85-102.

23. Emanuel, R.; Adams, J.N. College students' perceptions of campus sustainability. Int. J. Sustain. High. Educ. 2011, 12, 79-92. [CrossRef]

24. Barth, M.; Timm, J.M. Higher education for sustainable development: Students' perspectives on an innovative approach to educational change. J. Soc. Sci. 2011, 7, 13-23. [CrossRef]

25. Chaplin, G.; Wyton, P. Student engagement with sustainability: Understanding the value-action gap. Int. J. Sustain. High. Educ. 2014, 15, 404-417. [CrossRef]

26. Zeegers, Y.; Francis Clark, I. Students' perceptions of education for sustainable development. Int. J. Sustain. High. Educ. 2014, 15, 242-253. [CrossRef]

27. Abubakar, I.; Al-Shihri, F.; Ahmed, S. Students' Assessment of Campus Sustainability at the University of Dammam, Saudi Arabia. Sustainability 2016, 8, 59. [CrossRef]

28. Berke, P.R.; Conroy, M.M. Are We Planning for Sustainable Development? J. Am. Plan. Assoc. 2000, 66, 21-33. [CrossRef]

29. Lukman, R.; Glavič, P. What are the key elements of a sustainable university? Clean. Technol. Environ. Policy 2007, 9, 103-114. [CrossRef]

30. Waheed, B.; Khan, F.; Veitch, B. Developing a quantitative tool for sustainability assessment of HEIs. Int. J Sustain. High. Educ. 2011, 12, 355-368. [CrossRef]

31. Barlett, P.F.; Chase, G.W. Sustainability on Campus: Stories and Strategies for Change; MIT Press: Cambridge, MA, USA, 2004.

32. Alshuwaikhat, H.M.; Abubakar, I. An integrated approach to achieving campus sustainability: Assessment of the current campus environmental management practices. J. Clean. Prod. 2008, 16, 1777-1785. [CrossRef] 
33. United Nations Educational, Scientific and Cultural Organization (UNESCO). United Nations Decade of Education for Sustainable Development 2005-2014; UNESCO: Paris, France, 2004.

34. Cortese, A.D. Education for an environmentally sustainable future: A priority for environmental protection. Environ. Sci. Technol. 1992, 26, 1108-1111. [CrossRef]

35. Shriberg, M. Toward sustainable management: The University of Michigan Housing Division's approach. J. Clean. Prod. 2002, 10, 41-45. [CrossRef]

36. Grindsted, T.S. Sustainable universities: From declarations on sustainability in higher education to national law. Environ. Econ. 2011, 2, 29-36. [CrossRef]

37. Lozano, R.; Ceulemans, K.; Alonso-Almeida, M.; Huisingh, D.; Lozano, F.J.; Waas, T.; Lambrechts, W.; Lukman, R.; Hugé, J. A review of commitment and implementation of sustainable development in higher education: Results from a worldwide survey. J. Clean. Prod. 2015, 108, 1-18. [CrossRef]

38. Cortese, A.D. Mobilizing Higher Education to Create a Healthy, Just and Sustainable Society. In Proceedings of the Luther College Convocation, Decorah, IA, USA, 4 February 2010.

39. Stephens, J.C.; Hernandez, M.E.; Román, M.; Graham, A.C.; Scholz, R.W. Higher education as a change agent for sustainability in different cultures and contexts. Int. J. Sustain. High. Educ. 2008, 3, 317-338. [CrossRef]

40. Ministry of Economy and Planning, Kingdom of Saudi Arabia. The Eighth National Development Plan 2005-2009; Ministry of Economy and Planning: Riyadh, Saudi Arabia, 2005.

41. Ministry of Economy and Planning, Kingdom of Saudi Arabia. Seventh National Development Plan 2000-2004; Ministry of Economy and Planning: Riyadh, Saudi Arabia, 2000.

42. Ministry of Education (MOE). The Current Status of Higher Education in the Kingdom of Saudi Arabia; King Fahd National Library: Riyadh, Saudi Arabia, 2013.

43. Bernheim, A. How Green Is Green? Developing a Process for Determining Sustainability When Planning Campuses and Academic Buildings. Plan. High. Educ. 2003, 31, 99-110.

44. Bowser, G.; Gretzel, U.; Davis, E.; Brown, M. Educating the future of sustainability. Sustainability 2014, 6, 692-701. [CrossRef]

45. Bonney, M.; Duram, L. Applying AASHE STARS to Examine Geography's "Sense of Place" in Sustainability Education. J. Sustain. Educ. 2016, 11, 1-19.

46. UNESCO. Decade of Education for Sustainable Development-Mission, 2012. Available online: http: //www.unesco.org/science/wcs/eng/declaration_e.htm (accessed on 21 June 2016).

47. Jaramillo, A.; Melonio, T. Breaking Even or Breaking through: Reaching Financial Sustainability While Providing High Quality Standards in Higher Education in the Middle East and North Africa; World Bank: Washington, DC, USA, 2011.

(C) 2016 by the authors; licensee MDPI, Basel, Switzerland. This article is an open access article distributed under the terms and conditions of the Creative Commons Attribution (CC-BY) license (http://creativecommons.org/licenses/by/4.0/). 